\title{
Long-term soil hydrological data of a Pleistocene region in North-East Germany
}

\author{
Uwe Schindler $^{1^{\star}}$, Dietmar Barkusky ${ }^{2}$, Wilfried Mirschel ${ }^{3}$, Frank Eulenstein $^{4}$ \\ ${ }^{1}$ Leibniz Centre for Agricultural Landscape Research (ZALF), Müncheberg, Institute of Landscape \\ Hydrology, Eberswalder Str. 84, D-15374 Müncheberg, Germany, \\ ${ }^{2}$ Leibniz Centre for Agricultural Landscape Research (ZALF), Müncheberg, Research station, \\ Eberswalder Str. 84, D-15374 Müncheberg, Germany, \\ ${ }^{3}$ Leibniz Centre for Agricultural Landscape Research (ZALF), Müncheberg, Institute of Landscape \\ Systems Analysis, Eberswalder Str. 84, D-15374 Müncheberg, Germany, \\ ${ }^{4}$ Leibniz Centre for Agricultural Landscape Research (ZALF), Institute of Land Use Systems, \\ Eberswalder Str. 84, D-15374 Müncheberg, Germany \\ *email: schindler.rehfelde@gmail.com
}

\begin{abstract}
Long-term soil hydrological studies were carried out at the ZALF Müncheberg Experimental Station. Müncheberg is located in a Pleistocene end moraine landscape in NE Germany about $50 \mathrm{~km}$ east of Berlin and $40 \mathrm{~km}$ west of the Oder river, the border with Poland. The soils are formed on Pleistocene parent material, classified as Haplic Albeluvisol with a Bt horizon mostly beginning at about $70 \mathrm{~cm}$ depth. From 1994 to 1999 the site was used as arable land managed by different farming systems (integrated, integrated with irrigation, ecological and low input). From 2000 to 2005 the effect of different tillage systems (plough and no till) was investigated. Furthermore, soil water was extracted by use of suction cups for analysing the soil water nitrate concentrations. The data were used for quantifying deep drainage rates and nitrate losses as described in Schindler and Müller, 2008 and Schindler et al., 2010. All basic data (soil water content, tension, precipitation, potential evapotranspiration and soil water nitrate concentrations) are collected in the attached data base (DOI:10.4228/ZALF.1995.282).
\end{abstract}

Keywords: soil hydrological field measurements, water content, tension, nitrate, agriculture, land use, land management.

1 INTRODUCTION: Soil type, land use and agro-management practices as combined with the climatic conditions are decisive factors for seepage flow and solute leaching (Benson et al., 2006, Köhler et al., 2006, Schindler et al., 2010). Efficient water use and intelligent water management are essential for Northeast Germany as a region marked by an annual water balance deficit (Schindler et al., 2010). Throughout that region, measures are in demand to support groundwater recharge as well as wetland conservation.

Soil water content and tension are important hydrologic variables that reflect effects of land surface processes. However, there is a lack of reliable methods and measured values for quantifying deep seepage and solute leaching and predicting the effects of land use and climate changes on the soil water and solute status.

The impact of arable management on the water balance and nitrate leaching has been studied at the Müncheberg experimental field in the period between 1994 and 2005. The management data (crop, tillage, nitrogen fertilization, irrigation and harvest) and the yields are already published in Mirschel at al. (2007) and Mirschel et al. (2016). Here we present the associated soil hydrological data (soil water content, soil water tension, nitrate concentration of the seepage water) down to $3 \mathrm{~m}$ depth for the period 1994 to2005. Additional information is given to the soil, weather, agro-management and yields.

\section{MATERIAL AND METHODS}

2.1 SITE AND SOIL CHARACTERISTICS: The investigations were carried out at the Müncheberg Experimental Field of the ZALF (Leibniz Centre for Agricultural Landscape Research) with seepagedisposed sandy soils. Müncheberg is located in a Pleistocene end moraine landscape in NE Germany about $50 \mathrm{~km}$ east of Berlin and $40 \mathrm{~km}$ west of the Oder river, the border with Poland (Fig. 1). 
Figure 1. Experimental field at the ZALF Müncheberg with measurement plots (MP), left, and the scheme of the soil hydrological installations, right, georeferenced: $\mathrm{A}: 52^{\circ} 30^{\prime} 56.7^{\prime \prime} \mathrm{N} 14^{\circ} 07^{\prime} 21.4^{\prime \prime} \mathrm{E}$, B:

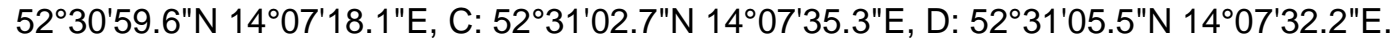

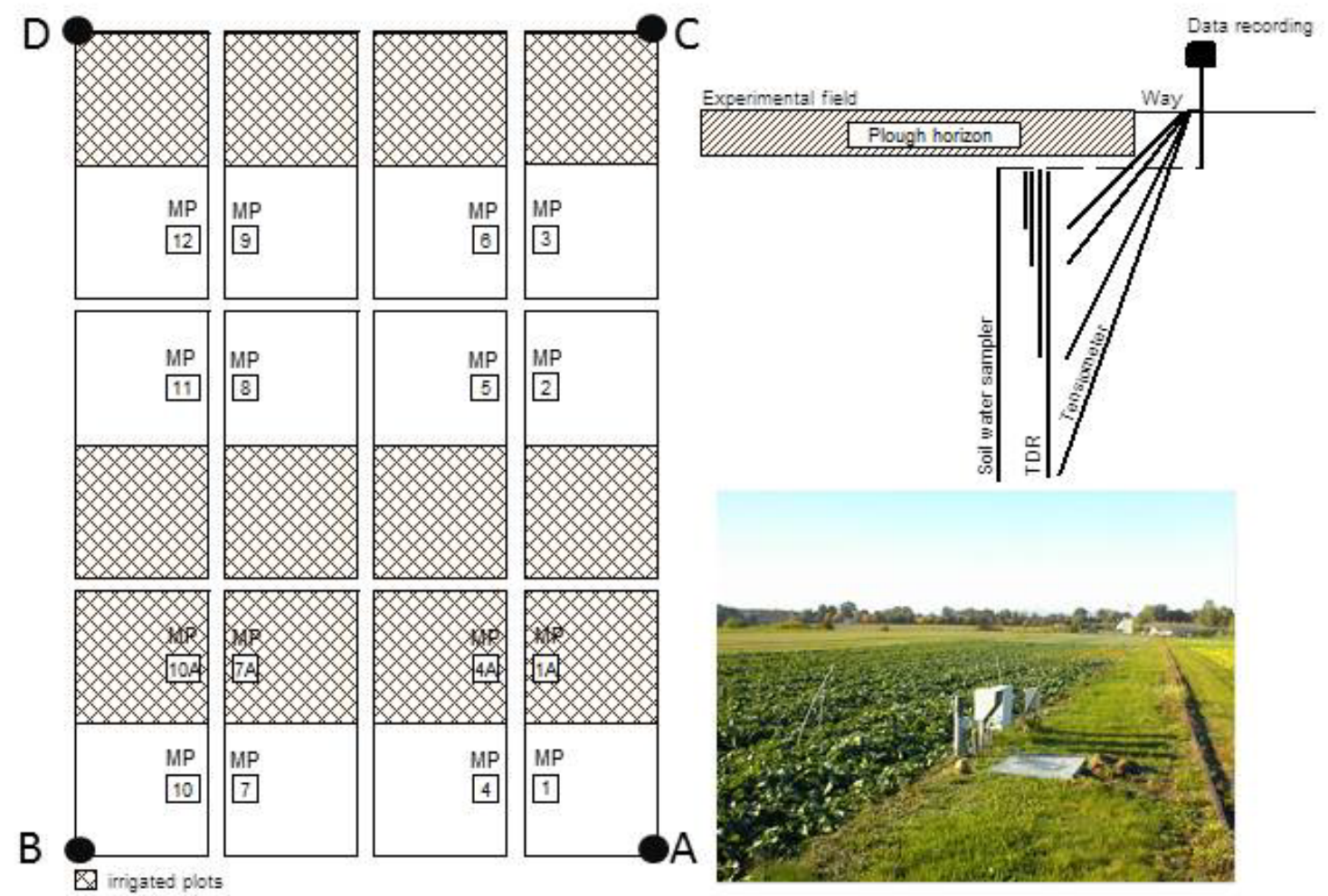

The experimental field consists of four parts ( $27 \mathrm{~m}$ wide and $298 \mathrm{~m}$ long). The total size is $32180 \mathrm{~m}^{2}$. The correct position of the measurement plots (MP) is given in Table 1.

\begin{tabular}{lll}
\hline \multicolumn{3}{l}{ Table 1. Georeference of the measurement plots. } \\
\hline Measurement plot (MP) & Northing & Easting \\
\hline MP1 & $52^{\circ} 30^{\prime} 57.8^{\prime \prime} \mathrm{N}$ & $14^{\circ} 07^{\prime} 22.0^{\prime \prime} \mathrm{E}$ \\
MP1A & $52^{\circ} 30^{\prime} 59.4^{\prime \prime N}$ & $14^{\circ} 07^{\prime} 24.6^{\prime \prime} \mathrm{E}$ \\
MP2 & $52^{\circ} 31^{\prime} 00.4^{\prime \prime N}$ & $14^{\circ} 07^{\prime} 27.2^{\prime \prime} \mathrm{E}$ \\
MP3 & $52^{\circ} 31^{\prime} 02.2^{\prime \prime} \mathrm{N}$ & $14^{\circ} 07^{\prime} 31.3^{\prime \prime} \mathrm{E}$ \\
MP4 & $52^{\circ} 30^{\prime} 58.8^{\prime \prime} \mathrm{N}$ & $14^{\circ} 07^{\prime} 22.1^{\prime \prime} \mathrm{E}$ \\
MP4A & $52^{\circ} 31^{\prime} 00.1^{\prime \prime N}$ & $14^{\circ} 07^{\prime} 25.1^{\prime \prime} \mathrm{E}$ \\
MP5 & $52^{\circ} 31^{\prime} 01.5^{\prime \prime N}$ & $14^{\circ} 07^{\prime} 28.2^{\prime \prime} \mathrm{E}$ \\
MP6 & $52^{\circ} 31^{\prime} 02.8^{\prime \prime} \mathrm{N}$ & $14^{\circ} 07^{\prime} 31.4^{\prime \prime} \mathrm{E}$ \\
MP7 & $52^{\circ} 31^{\prime} 01.0^{\prime \prime} \mathrm{N}$ & $14^{\circ} 07^{\prime} 19.6^{\prime \prime} \mathrm{E}$ \\
MP7A & $52^{\circ} 31^{\prime} 02.1^{\prime \prime} \mathrm{N}$ & $14^{\circ} 07^{\prime} 22.1^{\prime \prime} \mathrm{E}$ \\
MP8 & $52^{\circ} 31^{\prime} 03.6^{\prime \prime N}$ & $14^{\circ} 07^{\prime} 25.4^{\prime \prime} \mathrm{E}$ \\
MP9 & $52^{\circ} 31^{\prime} 05.2^{\prime \prime} \mathrm{N}$ & $14^{\circ} 07^{\prime} 28.8^{\prime \prime} \mathrm{E}$ \\
MP10 & $52^{\circ} 31^{\prime} 01.5^{\prime \prime} \mathrm{N}$ & $14^{\circ} 07^{\prime} 18.9^{\prime \prime} \mathrm{E}$ \\
MP10A & $52^{\circ} 31^{\prime} 02.7^{\prime \prime} \mathrm{N}$ & $14^{\circ} 07^{\prime} 21.5^{\prime \prime} \mathrm{E}$ \\
MP11 & $52^{\circ} 31^{\prime} 04.2^{\prime \prime N}$ & $14^{\circ} 07^{\prime} 24.88^{\prime \prime} \mathrm{E}$ \\
MP12 & $52^{\circ} 31^{\prime} 05.7^{\prime \prime} \mathrm{N}$ & $14^{\circ} 07^{\prime} 28.0^{\prime \prime} \mathrm{E}$ \\
\hline
\end{tabular}

Long-term average (1981 to 2010) annual precipitation is $562 \mathrm{~mm}$ (323 mm in summer, $239 \mathrm{~mm}$ in winter time, measured values). For the same climate period the average climatic water balance is -111 $\mathrm{mm}$ (variation between $131 \mathrm{~mm}$ and $-348 \mathrm{~mm}$ ) and the average air temperature is $9.1^{\circ} \mathrm{C}$ (variation between $7.2{ }^{\circ} \mathrm{C}$ and $10.4^{\circ} \mathrm{C}$ ) with increasing tendencies for both ones. Annual precipitation varied in the period 1994-2005 between $418 \mathrm{~mm}$ in 1999 and $760 \mathrm{~mm}$ in 2002. Average annual precipitation was $543 \mathrm{~mm}$ in this period and thus a little bit lower than the long-term average. 
Soils are formed on Pleistocene parent material, classified as Haplic Albeluvisol (WRB, 2006, Table 2) with a Bt horizon mostly beginning at about $70 \mathrm{~cm}$ depth. Thickness of the Bt horizon varies between 20 and $40 \mathrm{~cm}$. With the exception of the Bt horizon, sandy substrates are dominating. The particle size measurement was done by sedimentation (ISO 11277, 1994). The water retention values, dry bulk density and porosity were measured using the evaporation method (Schindler, 1980). More soil data are given in Mirschel et al., 2010 and Mirschel et al., 2016.

\begin{tabular}{lllllllll}
\hline \multicolumn{7}{l}{ Table 2. Soil parameters, Müncheberg Experimental Station } \\
\hline Horizon & $\begin{array}{l}\text { Depth } \\
\text { Cm }\end{array}$ & $\begin{array}{l}\text { Clay } \\
\%\end{array}$ & $\begin{array}{l}\text { Silt } \\
\%\end{array}$ & $\begin{array}{l}\text { Sand } \\
\%\end{array}$ & $\begin{array}{l}\text { DBD } \\
\mathrm{g} \mathrm{cm}^{-3}\end{array}$ & $\begin{array}{l}\text { Porosity } \\
\mathrm{cm}^{3} \mathrm{~cm}^{-3}\end{array}$ & $\begin{array}{l}\boldsymbol{\Theta}_{1} \\
\mathrm{~cm}^{3} \mathrm{~cm}^{-3}\end{array}$ & $\begin{array}{l}\boldsymbol{\Theta}_{2} \\
\mathrm{~cm}^{3} \mathrm{~cm}^{-3}\end{array}$ \\
\hline Ap & $0-30$ & 1 & 40 & 59 & 1.52 & 0.398 & 0.150 & 0.023 \\
BV & $30-70$ & 4 & 24 & 72 & 1.72 & 0.339 & 0.119 & 0.012 \\
Bt & $70-100$ & 9 & 65 & 26 & 1.71 & 0.334 & 0.161 & 0.050 \\
C & $>100$ & 1 & 22 & 77 & 1.70 & 0.344 & 0.073 & 0.009 \\
\hline
\end{tabular}

DBD - dry bulk density, $\Theta_{1}$ - water content at pF $2, \Theta_{2}$ - water content at pF 4.2

\subsection{STRUCTURE AND CONTENT OF DATA BASE}

The data base includes soil water content and tension data (raw data) of 16 measurement plots (MP) in different depths (see Table 5) in the period from 1995 to 2005. Furthermore soil water nitrate concentrations (sampling depths see Table 5), precipitation and potential evapotranspiration data calculated according to Wendling et al. (1991) are given. Methodical information to the methods and the measurements techniques are given in the following. The structure of the data base is according to Table 3.

Table 3. Database content and structure

\begin{tabular}{ll} 
Table 3. Database content and structure & \\
\hline Work sheet & Information and data \\
\hline V004_IMF_MP_WATER_CONTENT & Date DD.MM.YY \\
& MP ID \\
& Depth (cm) \\
& Soil water content (\% by vol.) \\
\hline V004_IMF_MP_TENSION & Date DD.MM.YY \\
& MP ID \\
& Depth (cm) \\
& Tension (kPa) \\
\hline V004_IMF_MP_PREC_PET & Date DD.MM.YY \\
& Precipitation (mm) \\
& Potential evapotranspiration (mm) \\
\hline V004_IMF_MP_NO3 & Date DD.MM.YY \\
& MP ID \\
& Depth (cm) \\
& Soil water nitrate concentration (mg $\left.\mathrm{NO}_{3}\right)$ \\
\hline
\end{tabular}

2.3 ARABLE MANAGEMENT SYSTEMS: In the period of measurements (1994-2005) four management systems were practised and investigated at the Müncheberg Experimental Field (Table 4). From 1994 to 1998 different farming systems which represent four different intensity levels were tested. Both, at the integrated and the low-input system mineral nitrogen fertilizer was applied. At the ecologic farming system exclusively organic nitrogen fertilizer (manure and slurry) was used. From 1999 to 2000 a break was inserted cultivating Lucerne / grass mixture at all plots. In 2001 tillage experiments started. The effect of two soil tillage systems $(\mathrm{i}-$ plough $(22-25 \mathrm{~cm})$ in combination with tooth cultivator $(15 \mathrm{~cm})$, ii - reduced tillage with seedbed preparation $(8-12 \mathrm{~cm})$ using a rotary cultivator) on yield, soil water and the solute balances was investigated. In the period 1994-2005 the crop rotations were:

1994-1998: $\quad$ Sugar beet - winter wheat - winter barley - winter rye (including catch crops)

1999-2000: $\quad$ Lucerne/grass mixture at all plots

2001-2005: With plough: Winter wheat - winter barley - winter oilseed rape - triticale

- winter rye (including oil radish) - potato

Reduced tillage: Winter wheat (including oil radish as catch crop) - silage maize winter rye (including oil radish as catch crop) - forage peas - winter barley - winter oilseed rape 
Table 4 provides an overview of the average annual nitrogen fertilizer input $\left(\mathrm{N}_{\text {total }}\right)$, the annual amount of irrigation water (I) of the management systems as an average over all repetitions within the considered period and the yield in t GE/ha. GE is an accounting unit on the energy basis of the crop yield ( $1 \mathrm{~kg}$ barley $=12.56 \mathrm{MJ}$ specifically aggregated metabolisable energy) and enables the yield comparability of different crops, according to the Cereal Unit (Brankatschk and Finkbeiner, 2014). $1 \mathrm{t}$ GE/ha is defined as a yield of $1000 \mathrm{~kg} / \mathrm{ha}$ of barley (i.e. $1000 \mathrm{~kg} / \mathrm{ha}$ of wheat yield are equivalent to $1.07 \mathrm{t} \mathrm{GE} / \mathrm{ha}, 1000 \mathrm{~kg} / \mathrm{ha}$ of rye yield are equivalent to $1.01 \mathrm{t} \mathrm{GE} / \mathrm{ha}$ and $1000 \mathrm{~kg} / \mathrm{ha}$ of winter rape yield are equivalent to $2.46 \mathrm{t} \mathrm{GE/ha} \mathrm{(Alsing} \mathrm{et} \mathrm{al.,} \mathrm{2002).} \mathrm{The} \mathrm{irrigation} \mathrm{management} \mathrm{was} \mathrm{realized}$ using the irrigation scheduling system BEREST90 (Wenkel and Mirschel, 1991). Detailed crop, yield and management information are given in Mirschel et al., 2010 (DOI:10.4228/ZALF.1992.167) and Mirschel et al., 2016 (DOI:10.4228/ZALF.1992.271.

Table 4. Average annual management data, Müncheberg Experimental Station, 1994-2005

\begin{tabular}{lllccc}
\hline Period & Management system & $\begin{array}{l}\text { MP number } \\
\text { (acc. Fig. 1) }\end{array}$ & $\begin{array}{c}\mathrm{N}_{\text {total }} \\
\mathrm{kg} \mathrm{ha}^{-1}\end{array}$ & $\begin{array}{c}\mathrm{I} \\
\mathrm{mm} \mathrm{a}^{-1}\end{array}$ & $\begin{array}{c}\mathrm{Yield}^{-1} \\
\mathrm{t} \mathrm{GE}^{13} \mathrm{ha}^{-1}\end{array}$ \\
\hline 1994-1998 & - IO: Integrated without irrigation & 1, 4, 7,10 & 112 & 0 & 7.6 \\
& - IB: Integrated with irrigation & 1A, 4A, 7A, 10A & 126 & 78 & 8.6 \\
& - OO: Ecologic without irrigation & $2,5,8,11$ & $45^{2)}$ & 0 & 4.3 \\
- EO: Low-input without irrigation & $2,6,9,12$ & 86 & 0 & 7.3 \\
1999-2000 & - Lucerne grass & all plots & & 0 & \\
$2001-2005$ & - P: Plough with tooth cultivator & $1,3,5,7,9,11$, & 165 & 0 & 5.9 \\
& - NT: Reduced tillage & $2,4,6,8,10,12$ & 146 & 0 & 6.2 \\
\hline
\end{tabular}

${ }^{1)} \mathrm{t} \mathrm{GE} \mathrm{ha}^{-1}$ - accounting unit for different crops, see above ${ }^{2)}$ only manure and slurry, I- irrigation water

2.4 SOIL HYDROLOGICAL MEASUREMENTS: Water and solute movement through the vadose zone should be compartmentalised into: (i) movement through the root zone, and (ii) movement below the root zone (Gee and Hillel, 1988). Fluxes within the root zone are spatially and temporally variable. Fluxes below the root zone may be transient or steady-state (Gee and Hillel, 1988, Schindler and Müller, 1998).

The basic idea was to detect seepage flow preferably below the root zone where soil water movement is directed predominantly downwards, changes in the soil hydrologic status will proceed slowly and continuously, and rainfall events or fluctuations of evapotranspiration will not produce distinct changes in soil water content and tension.

Regular measurements of tensions with water filled pressure transducer tensiometers (accuracy 1 $\mathrm{hPa}$ ) and water contents with TDR probes at 16 soil hydrological plots were carried out at several depths down to $3 \mathrm{~m}$ depth (Table 5). The tension values were recorded in daily intervals. The soil water content was measured in 3 day intervals with the TDR Easy test device (Easy Test, 2011). Suction cups were used for the soil water extraction. Based on the soil tension measurement at 2 and $3 \mathrm{~m}$ depth, the proof may be given directly from the hydraulic gradient for downward water movement, or where required, periods of capillary rise may be detached. The instruments were buried to enable agricultural equipment to pass over the measuring plots. The installation scheme of soil water samplers, TDR probes and tensiometers is given in Fig. 1 (right side). They all are located within the MP's $(1.5 \mathrm{~m} \times 1.0 \mathrm{~m})$ below the plough horizon in a distance of $3 \mathrm{~m}$ far from the field edge

Precipitation was measured at $1.10 \mathrm{~m}$ above the ground using a headed and wind-shielded gauge (type HP 3) with a sampling area of $200 \mathrm{~cm}^{2}$ coupled with a see-saw technique according to JossTognini with a read contact (resolution: $0.1 \mathrm{~mm}$ ). Temperature, relative air humidity, global radiation and some other meteorological variables were measured by the automatic micro-meteorological station FMA 86 (type Weihenstephan, produced by Lambrecht GmbH Göttingen, Germany). More details are given in Mirschel et al. (2007). The soil water has been extracted with the soil water samplers (suction cups). The nitrate concentration of the seepage water was analysed in the laboratory of the ZALF. Taking deep seepage dynamics into consideration, nitrogen losses were estimated (Schindler and Müller, 1998 and Schindler et al., 2010). All basic data (soil water content, tension, precipitation, potential evapotranspiration and soil water nitrate concentrations) are collected in the attached data base (DOI:10.4228/ZALF.1995.282). 


\begin{tabular}{|c|c|c|c|c|c|c|c|c|c|c|c|c|c|c|c|}
\hline \multirow[t]{3}{*}{ MP } & \multicolumn{7}{|c|}{ Soil water content (\% by vol) } & \multicolumn{5}{|c|}{ Tension (kPa) } & \multicolumn{3}{|c|}{ SWS } \\
\hline & \multicolumn{15}{|c|}{ Depth below ground $(\mathrm{cm})$} \\
\hline & 5 & 100 & 120 & 150 & 200 & 300 & 500 & 120 & 150 & 200 & 300 & 500 & 150 & 200 & 300 \\
\hline MP1 & * & & * & * & * & * & & * & * & * & * & & * & $*$ & ${ }^{*}$ \\
\hline MP1A & * & * & & & * & * & & & & & * & & & & * \\
\hline MP2 & * & & * & * & * & * & * & * & * & * & * & * & * & * & * \\
\hline MP3 & * & & * & * & * & * & & * & * & * & * & & * & * & * \\
\hline MP4 & * & * & & & * & * & & & & & * & & & & * \\
\hline MP4A & * & * & & & * & * & & & & & * & & & & * \\
\hline MP5 & * & * & & & * & * & & & & & * & & & & * \\
\hline MP6 & * & * & & & * & * & & & & & * & & & & * \\
\hline MP7 & $*$ & * & & & * & * & & & & & $*$ & & & & * \\
\hline MP7A & * & * & & & * & * & & & & & * & & & & * \\
\hline MP8 & * & * & & & * & * & & & & & * & & & & * \\
\hline MP9 & * & * & & & * & * & & & & & * & & & & * \\
\hline MP10 & * & * & & & * & * & & & & & * & & & & * \\
\hline MP10A & * & * & & & * & * & & & & & * & & & & * \\
\hline MP11 & * & * & & & * & * & & & & & * & & & & * \\
\hline MP12 & * & * & & & * & * & & & & & * & & & & * \\
\hline
\end{tabular}

SWS - soil water samples (suction cups)

\section{CONCLUSIONS}

The tension, the water content, the seepage and the nitrate leaching data were measured with high accuracy in a period longer than 10 years. These data reflect crop and management conditions on the field and show the time delay of soil processes as a function of soil depth. They could be a very good basis for improving crop growth, soil water, soil nitrogen and complex agro-ecosystem models.

\section{REFERENCES}

Alsing, I., Fleischmann, A., Guthy, K., Hechler, G., Rossbauer, G., Schmaunz, F., Ruhdel, H.-J., Schlaghecken, J., Schneieder-Böttcher, I.: Lexikon Landwirtschaft. 4. Überarbeitete und erweiterte Auflage, Eugen Ulmer GmbH \& Co., Stuttgart, 909 pp., 2002

Benson, V.S., van Leeuwen, J.A., Sanchez, J., Dohoo, I.R. and Somers, G.H.: Spatial Analysis of land use impact on ground water nitrate concentrations. J. Environ. Qual. 35. 421-432, 2006.

Brankatschk, G., Finkbeiner, M.: Application of the Cereal Unit in a new allocation procedure for agricultural life cycle assessment. Journal for Cleaner Production 73:72-79, 2014.

Easy Test: Institute of Agrophysics. Lublin. Poland, http://www.shailrontechnology.com/range/upload/TDR\%20Soil\%20Moistur\%20Meter\%20(Han d\%20Held).pdf, 2011

Gee, G.W. and Hillel, D.: Groundwater recharge in arid regions: Review and critique of estimation methods. J. Hydrol. Process 2:255-266, 1988:

ISO 11277: Bodenbeschaffenheit - Bestimmung der Partikelgröflenverteilung in Mineralböden Verfahren durch Sieben und Sedimentation nach Entfernen der löslichen Salze der organischen Substanz und der Carbonate. Beuth-Verlag. Berlin. 44 pp. 1994.

Köhler, K., Duijnisveld, W.H.M. and Böttcher, J.: Nitrogen fertilization and nitrate leaching into groundwater on arable sandy soils. J Plant Nutr. Soil Sci. 169, 185-195, 2006).

Mirschel, W., Wenkel, K.-O., Wegehenkel, M., Kersebaum, K.C., Schindler, U., Hecker, J.-M.: Müncheberg field trial data set for agro-ecosystem model validation. In: Kersebaum,K.C., Hecker, J.-M., Mirschel, W.; Wegehenkel, M. (eds.): Modelling Water and Nutrient Dynamics in Soil-Crop Systems: proceedings of the workshop on "Modelling water and nutrient dynamics in soil-crop systems" held on 14-16 June 2004 in Müncheberg, Germany, pp. 219-243, Dordrecht (Springer), 2007

Mirschel, W., Wenkel, K.-O., Wegehenkel, M., Kersebaum, K.C., Schindler, U.: Comprehensive multivariable field data set for agro-ecosystem modelling from Müncheberg Experimental Station in 1992 - 1998; Leibniz-Zentrum für Agrarlandschaftsforschung (ZALF) e.V. https://doi.org/10.4228/ZALF.1992.167, 2010.

Mirschel, W, Barkusky, D., Hufnagel, J., Kersebaum, K.C., Nendel, C., Laacke, L., Luzi, K., Rosner, G.: Coherent multi-variable field data set of an intensive cropping system for agro-ecosystem 
modelling from Müncheberg, Germany, Open Data Journal for Agricultural Research, vol.2, 110, 2016. https://doi.org/10.4228/ZALF.1992.271.

Schindler, U.: Ein Schnellverfahren zur Messung der Wasserleitfähigkeit im teilgesättigten Boden an Stechzylinderproben. Arch. Acker- u. Pflanzenbau u. Bodenkd., Berlin 24: 1-7, 1980.

Schindler, U. and Müller, L.,. Methods for the quantification of soil drainage rates in the north-east German lowlands. Proceedings of the 7th International Drainage Symposium, March 8-11, Orlando, Fl, 613-620, 1998.

Schindler, U., Müller, L., Dannowski, R., Barkusky, D. and Francis, G.: Long-term measurements to quantify the impact of arable management practices on deep seepage and nitrate leaching. In: Long-term ecological research: between theory and application. Springer Science+Business Media B.V, Dordrecht, pp. 243-252, 2010.

Wendling, R., Schellin, H.-G. and Thomä, M.: Bereitstellung von täglichen Informationen zum Wasserhaushalt des Bodens für die Zwecke der agrarmeteorologischen Beratung. Z. f. Meteorologie 41, S. 468-474, 1991.WRB: World Reference Base for Soil Resources, A Framework for International Classification, Correlation and Communication, FAO Rome, 2006, World Soil Resources Reports 103, 145p., 2006.

Wenkel, K.-O. and Mirschel, W.: BERSIM und BEREST90 - Modelle zur Simulation der Bodenfeuchte und Evapotranspiration sowie zur operativen Beregnungseinsatzsteuerung im integrierten Landbau. Agrarinformatik 21: 349-360, 1991. 